\title{
Uma feminista marxista: entrevista com Maria Lygia Quartim de Moraes
}

\author{
A Marxist Feminist: interview with \\ Maria Lygia Quartim de Moraes
}

\section{Danielle Tega ${ }^{\mathrm{a}} \odot$}

Maria Lygia Quartim de Moraes é socióloga, professora titular aposentada da Universidade Estadual de Campinas (Unicamp) e pesquisadora do Núcleo de Estudos de Gênero - Pagu. Atualmente, é professora colaboradora da Pós-Graduação em Sociologia da Unicamp e professora visitante da Pós-Graduação em Serviço Social e Políticas Sociais da Universidade Federal de São Paulo (Unifesp). Coordena o grupo de pesquisa "Teorias e militâncias feministas" e integra o grupo de trabalho "Estado laico" da Sociedade Brasileira para o Progresso da Ciência (SBPC).

A entrevista foi realizada por meio da plataforma Google Meet nos dias $24 \mathrm{e}$ 25 de março de 2021, totalizando duração de três horas e quarenta e oito minutos. Para respeitar os critérios desta revista, passagens foram retiradas em comum acordo com a entrevistada, que gentilmente complementou, por escrito, trechos solicitados. Esta versão final priorizou a trajetória intelectual de Maria Lygia, percorrendo sua formação política e acadêmica, tanto no Brasil como no exílio, além de sua militância em organizações de esquerda e grupos feministas. Ganham relevância as personagens recordadas em seus respectivos contextos históricos, além das reflexões da socióloga sobre os diálogos entre marxismo e feminismo nos diferentes momentos de sua jornada.

Revista Plural Hojeé dia 24 de março de 2021. Estamos gravando esta conversa na data em que o Brasil deve ultrapassar, oficialmente, 300 mil mortes de pessoas por Covid-19. Gostaria de começar agradecendo pela entrevista, pois estamos em tempos difíceis.

Maria Lygia Quartim de Moraes Dia 24 de março é também o Dia da Verdade, Memória e Justiça na Argentina. Não é indiferente dizer que hoje todo mundo está sob uma apreensão enorme. O número de mortes já atingiu 300 mil, mas, segun-

a Danielle Tega é professora na Universidade Estadual de Mato Grosso do Sul - UEMS e pesquisadora associada ao Centro Latino-Americano de Estudos em Cultura - CLAEC.

E-mail: dani.tega@uol.com.br. 
do todos os prognósticos, vai ser ainda maior. Somos governados por um psicopata - e, diferente da Argentina, não fizemos um trabalho de memória. As pessoas estão com fome e estão desesperadas; só não estão nas ruas porque os movimentos sociais estão sendo contidos para não espalhar ainda mais a Covid-19. Na minha percepção, é mais um momento de ruptura que está acontecendo, que chamamos de "momento de passagem". A perspectiva não é muito otimista e penso que já foi feito um corte com aquilo que ficou para trás. Concordo com o historiador francês Jérôme Baschet quando diz que o século XXI começou agora, assim como o século XX começou, de fato, com a Primeira Guerra Mundial.

Revista Plural Você poderia falar a respeito de sua família e sua formação inicial? Como eram os ambientes social, afetivo e intelectual nos quais você cresceu? Maria Lygia Quartim de Moraes É importante situar que cresci num dos períodos mais democráticos do Brasil, no final da Segunda Guerra, quando a ditadura do Getúlio Vargas se esvaía e a nova ordem era a democracia. Nasci em 1943 e, até 1964, ano do golpe militar, foram praticamente 20 anos. Quando você nasce e passa sua adolescência em certo contexto, acaba naturalizando a situação que sempre conheceu. Eu traço um paralelo com a geração das minhas netas, que nasceram nos anos 1990: o espanto delas com a situação que estão vivendo agora é da ordem do terror, do inexplicável.

Marcando esse período de estabilidade, o Brasil dos anos 1950 é um país conservador, no qual a Igreja Católica é a grande referência de normas. Cresci numa família de classe média ascendente, com certo conforto. Meu pai e minha mãe se relacionavam com grupos altamente intelectualizados. As mulheres, via de regra, não trabalhavam. Já a maior parte dos homens ou vivia de renda ou tinha algum cargo de governo, como promotor. Eram pessoas que podiam estudar muito. Meu pai tinha graduação em direito, mas trabalhava em comércio. Ele tinha uma trajetória profissional muito ziguezagueante. Do lado da minha mãe havia também pessoas com estudo, curso superior e posição política, como minha tia Nadir Kfouri, que foi reitora da PUC [Pontifícia Universidade Católica] e era uma católica de esquerda ${ }^{1}$.

1 Nadir Gouvêa Kfouri estava em sua primeira gestão à frente da universidade quando, em 1977, o coronel Erasmo Dias, então secretário de Segurança Pública de São Paulo, liderou uma invasão policial no campus da PUC. A repressão teve como consequência a prisão de centenas de estudantes, além de feridos e feridas. Como comprovado em diferentes documentos, relatos e fotos da época, Nadir Kfouri repudiou a violência do ato e se recusou a cumprimentar Erasmo Dias, dizendo que não dava a mão a assassinos. Com esse gesto, tornou-se importante figura da resistência à ditadura. 
A grande vantagem em relação à minha vida familiar era que, coisa rara, meu pai e minha mãe eram apaixonados um pelo outro. Um casal que gostava muito dos filhos, mas que tinha uma relação muito forte entre homem e mulher. E você tem a tendência a projetar, na vida de todo mundo, a sua própria experiência. Só depois fui percebendo que os casais se odiavam, ou viviam como irmã e irmão, não tinham uma vida própria do casal. Talvez por essa boa lembrança, meus irmãos e eu sempre acabamos casando [risos].

Minha mãe era uma pessoa extremamente generosa. Era uma mulher preocupada em ler, em aprender francês; tinha um cuidado com a elegância, com a mesa bem posta. Havia conforto material, que era algo agradável. Até meus pais terem casa própria, passamos por um momento mais difícil, em que moramos em casa de parentes. Mas, aos sete anos de idade, quando nos mudamos para o Itaim, realizei meu sonho, a grande fantasia de ter meu quarto próprio - e Virginia Woolf tem toda razão sobre a importância de ter um quarto para si ${ }^{2}$, algo que tenho até hoje, que é meu espaço privado.

Como acontece com todas as famílias, nossos pais definiram nossos nomes e projetos de vida. Para o João [Quartim de Moraes], meu pai projetou o filho intelectual. Aliás, a fantasia do meu pai era que meu irmão fosse diplomata. $\mathrm{O}$ meu destino era outro. Minha mãe se chamava Lygia, eu já era Maria Lygia, então um pouco mais chique. E comecei a viver a fantasia da minha mãe: Maria Lygia Quartim de Moraes vai ser da alta sociedade, todas aquelas projeções. Para preencher os sonhos dos meus pais, o João foi para o colégio de padres, o São Luís, e eu fui para o colégio de freiras, o Sacré-Coeur. E foi assim que nos tornamos um ateu e outra ateia.

Nossa casa sempre foi muito aberta, era uma casa muito gostosa onde os jovens gostavam de ir. Tanto meus pais como meu irmão recebiam muitos amigos. Eu digo que tive sorte de ser a segunda filha porque, nesse padrão de generificação, evidentemente que os meus presentes eram bonecas, coisas assim. Mas meu irmão ganhava livros e eu os lia, então não tinha tanto problema. Cresci entre homens, numa família em que eu fui a única mulher até os 12 anos de idade, mas na qual as mulheres eram respeitadas. Então, pensando bem, eu fui privilegiada.

Revista Plural Sua graduação em Ciências Sociais (1963-1966), na USP (Universidade de São Paulo), ocorreu em um momento conflituoso e efervescente nos

2 Referência ao livro Um teto todo seu, da escritora britânica Virginia Woolf (2004), publicado originalmente em 1929. 
âmbitos político e cultural do país. O que a levou a escolher esse curso? Como foram esses anos de formação universitária? Em que momento inicia sua formação marxista?

Maria Lygia Quartim de Moraes Minha casa vivia cheia de rapazes e um dos que eu mais gostava se chamava Norberto Nehring, que era o maior amigo do João. Norberto e eu fomos grandes amigos, eu o convidei para ser meu par na formatura do ginásio. Depois a gente começou a namorar.

Aquele era o momento das Ligas Camponesas, do estouro de várias injustiças sociais. Nossa tendência já era "coração de esquerda". Eu tinha uns 17 anos quando o Norberto me deu o livro da Simone de Beauvoir, Todos os homens são mortais, que é um romance maravilhoso. O livro aborda a ideia de liberdade da Simone: nós nascemos livres, nossa liberdade é situada e nossa finitude é o que dá sentido aos nossos projetos, ao modo como usamos nosso tempo de vida. Achei a Simone extraordinária e li, depois, $O$ segundo sexo. Então foi pela Simone de Beauvoir que, lá em casa, a primeira que se tornou socialista fui eu.

O Norberto trabalhava como químico industrial durante o dia e decidiu cursar Economia no período noturno. Naquela altura, a Faculdade de Economia ficava na Rua Doutor Vila Nova, e a de Ciências Sociais na Rua Maria Antônia, ao lado uma da outra. Eu não sabia o que fazer na graduação exatamente. João realizou um dos sonhos do meu pai e cursava Direito na USP, que ele detestava, para ser diplomata. Depois ele entrou na Faculdade de Filosofia, fazia um curso em cada período. E foi o João quem comentou comigo sobre o curso de Ciências Sociais, disse que eu ia gostar, que tinha Sociologia e um pouco de tudo. Além disso, meu irmão também participava do segundo grupo que lia $O$ capital $^{3}$ e, como boa parte das reuniões era lá em casa, de certa forma fui conhecendo alguns professores: Célia Quirino, Eduardo Kulgmann, Roberto Schwarz, que tinha acabado de voltar dos EUA, e assim por diante.

Escolhido o curso, foi aquela história do "tinha que dar tudo certo", aquela arrogância juvenil. Terminei o colegial e pensei: "vamos fazer o vestibular, eu para Ciências Sociais e o Norberto para Economia, os dois para o período noturno, e a gente se casa em março". Entrei na faculdade em 1963. Eram os figurões que davam aula, Fernando Henrique [Cardoso], Octavio Ianni, estavam todos lá. Mas

3 O "Grupo do Capital" ou "Seminário Marx" foi composto por professores e discentes da USP com o objetivo de estudar a obra do pensador alemão. A primeira formação do grupo, de 1958 a 1964, preocupou-se em realizar uma leitura rigorosamente acadêmica. A segunda formação, parcialmente inspirada na anterior, teve encontros a partir de 1963 e, após o golpe, "acabou entrando para a luta social de maneira mais direta”, com um espírito "mais ativista", conforme relata Roberto Schwarz (2017, p.18), participante dos dois seminários. 
o Francisco Weffort dando aula de Ciência Política e o Fernando Novais dando aula de História valeram por toda a faculdade!

Fiquei grávida ainda no primeiro ano. Não foi uma gravidez planejada, mas foi bem aceita. Escolhi meu querido primo, que era muito próximo do Norberto, o Juca Kfouri, como padrinho. Como a gente não tinha muito dinheiro, alugamos um apartamento perto da casa da minha mãe; eu comia na casa dela e o Juca também ia lá para ficar com a Marta, minha filha. Éramos muito jovens, eu tinha 19 anos, o Norberto, 20 e poucos. Aí, em 1964, foi aquela brutalidade. É um pouco a sensação horrorosa que estamos vivendo agora. Mas imagina se, além do [Jair] Bolsonaro, tivesse realmente uma ditadura. Porque, bem, ou mal, o Bolsonaro foi eleito.

Eu entrei para o PCB [Partido Comunista Brasileiro] no primeiro ano de graduação. Lembro que, na minha classe, a maioria esmagadora era homens, acho que uns 25 homens e cinco mulheres. Uma delas era da AP [Ação Popular], a Regina. Eu me aproximei mais da Iara, que era do PCB, e sondei para saber como eu poderia entrar no partido, pois já tinha decidido que queria ser comunista. Ela disse: "Olha, tem dois partidos comunistas". Eu perguntei: "Como assim?”. E ela explicou que teve uma cisão. Aí eu falei: “Eu quero o do Prestes!”. Era o partido que ela estava, então entrei na "base da base da base" do PCB. Era incrível! O CPC [Centro Popular de Cultura] tinha gênios como o Mário Schenberg dando aulas de economia política. Falei pra Iara que o Norberto também queria entrar no partido, então um cara do PCB que estava na Faculdade de Economia o procurou. Mas a Economia era muito reacionária. O pai de uma amiga de infância era professor lá, um fascista. No primeiro dia de aula, ele disse: "Se tiver algum comunista aqui, saiba que é meu inimigo pessoal”. Nessa ocasião, o Norberto já tinha entrado no partido. Devia ter uns três ou quatro comunistas na turma dele. Quando passaram a lista de chamada, alguém escreveu, ao lado do nome do Norberto, "comunista". Aí o Norberto disse que não teve jeito: ao pegar a lista, escreveu "comunista" ao lado de todos os outros nomes também [risos].

Para tentar resumir essa formação inicial, foram fundamentais minhas leituras da Simone de Beauvoir para meu entendimento do socialismo, a militância no PCB e, claro, as disciplinas na USP para o debate do marxismo. Fiz duas disciplinas com Octavio Ianni e outras duas com Florestan Fernandes que, naquele momento, escrevia A Revolução Burguesa no Brasil ${ }^{4}$ e debatia nas aulas suas ideias.

Naquela época não tinha mestrado, você podia ir direto para o doutorado ou, como a Helleieth Saffioti e o Bento Prado fizeram, ir direto para a livre-docência.

4 Embora tenha sido publicado pela primeira vez em 1975, Florestan Fernandes (2005) elucida, na "Nota explicativa", que seu livro começou a ser escrito no primeiro semestre de 1966. 
Era o antigo regime de pós-graduação e esse sistema só foi alterado pela ditadura militar. Terminei a graduação e iniciei uma pós-graduação de dois anos com bolsa da Fapesp [Fundação e Amparo à Pesquisa do Estado de São Paulo] e orientação da Paula Beiguelman. Examinei a Primeira República, de 1920 a 1930, fazendo pesquisa no arquivo [Arquivo Público do Estado de São Paulo] que ficava numa travessa da Rua Augusta. Consultei todos os jornais de São Paulo dessas duas décadas, que eram o Correio Paulistano, o Estado de São Paulo e, depois, o Diário Nacional. Li todas as edições diárias do período porque era fascinante! O Warren Dean, pesquisador americano, também fazia isso.

Finalizada essa etapa, eu já estava com o projeto de doutorado pronto e enviado para a Fapesp - agora com a orientação do Fernando Henrique Cardoso. Ele tinha feito uma coisa que foi bem oportunista na época, porque nós éramos contra o sistema de cátedra. No final de 1968, ele disputou a Cátedra de Política, apesar de ser sociólogo, e ganhou. A confraria da "macharia” lá se reuniu e deu [o cargo] pra ele. Foi um escândalo aquele concurso! De qualquer maneira, eu trabalhava na cadeira de Política, tinha bolsa da Fapesp, e continuei. A minha relação com o Fernando sempre foi muito civilizada: o Fernando é muito educado, o Fernando professor, o Fernando orientador, não tenho queixas. Por outro lado, nunca votei nele. Mentira, votei nele para Senador. Mas, depois, nunca mais.

Alguns alunos já haviam sido escolhidos para serem os futuros assistentes: o Roberto Gambini, a Ana Maria Amaral, o André Villalobos e eu. Até 1968, dentro da loucura, havia certa normalidade. Porém, na hora em que passamos para a luta armada, para a resistência armada, aí a vida ficou muito esquizofrênica ${ }^{5}$. Por um lado, tudo normal, o trabalho, o estudo; por outro, as ações, o medo permanente. Tinha o fato de que, além da polícia, havia os grupos de extrema direita, como o CCC [Comando de Caça aos Comunistas]. Foi uma época muito intensa e muito tensa. E o que aconteceu? O AI- $5^{6}$ cassou não somente o Fernando, como mais de 200 professores da USP e a diretoria da Fapesp. Fim da bolsa e de quaisquer perspectivas de trabalho acadêmico. Todas as portas se fecharam e a situação estava por um fio. Norberto foi preso e ficou detido no DOPS [Departamento de Ordem Política e Social] por cerca de 15 dias. Fizemos muita pressão e ele foi solto

5 Referência ao período no qual a entrevistada e seu marido passam a atuar na Ação Libertadora Nacional (ALN), organização revolucionária criada em 1968 por dissidentes do PCB.

6 Promulgado em 13 de dezembro de 1968 pelo ditador Costa e Silva, o Ato Institucional $n^{0} 5$ (AI-5) permitia a cassação de mandatos parlamentares, a suspensão dos direitos políticos de qualquer cidadão, o fechamento do Congresso Nacional, a intervenção nos estados e municípios, a suspensão da garantia do habeas-corpus, entre outros dispositivos repressivos. 
para poder estar no aniversário de cinco anos da Marta. Foi quando ele tomou a decisão de ir para Cuba, onde o reencontrei meio ano depois.

Revista Plural Você ficou seis anos no exílio, passando por Cuba, Chile e França (1969-1975). Novamente, em um momento de intensa mobilização política, social e cultural. Ao mesmo tempo, você não deixou de lado sua formação acadêmica. Quais foram suas principais referências teóricas e políticas no período? Com quais grupos debatia e quais temas?

Maria Lygia Quartim de Moraes Além da formação acadêmica oficial, importante para meu currículo, acho que um grande mentor intelectual, que também foi a pessoa que mais formou jovens brasileiros no exterior, foi meu irmão João. Ele sempre fez seminários de formação. Em 1970, eu estava em Paris quando o Norberto foi preso e assassinado pelos órgãos de repressão política da ditadura. Como uma forma de segurar a dor, li, por conta própria, o primeiro tomo da edição francesa d'O capital. Eu já havia lido algumas coisas, mas, naquele momento, sistematizei para ler integralmente. O João, que já havia lido o primeiro e o segundo tomos, propôs um seminário de estudos sobre o terceiro tomo do livro. Apesar de ter sido um livro que o Marx não chegou a terminar, sendo finalizado por Engels, essa obra apresentava a discussão da divisão da mais-valia entre as classes dominantes fundamentais, os proprietários de terra e os industriais. $\mathrm{E}$ a questão da terra estava na grande disputa da esquerda da época: por um lado, o pessoal do PCdoB [Partido Comunista do Brasil] achava que o Brasil ainda tinha elementos feudais e defendia o cerco da cidade pelo campo; por outro, o pessoal do PCB achava que não, defendendo uma aliança com a burguesia nacional. Nós líamos não somente $O$ capital, mas também textos do grande Alberto Passos [Guimarães] e do Antonio Barros de Castro. Os encontros eram semanais e o grupo era excelente; participavam Ana Maria Amaral, Paulo Sérgio Pinheiro, Aloysio Nunes Ferreira, Maryse Farhi, entre outros. Ao mesmo tempo, iniciei meus estudos no doutorado em Sociologia do Desenvolvimento da Universidade de Paris I.

Depois, quando fomos para o Chile, encontramos um país desigual, uma burguesia asquerosa, conservadora, racista e machista. Diferente da França, não tinha um café decente. Mas tinha o Allende! E tinha o movimento popular. Acompanhar aquele processo valeu a pena, apesar de todo pavor que marcou seu fim. Aquilo que foi destruição! Pelo que acompanhei no Chile, eu vejo algo parecido acontecendo aqui no Brasil, essa insistência em apagar a memória, em reescrever acontecimentos históricos. Até hoje, tenho horror de bater panelas porque me lembro 
das mulheres chilenas que batiam panelas para desestabilizar aquele governo democrático maravilhoso! Por isso, uso um pandeiro para protestar "Fora, Bolsonaro!".

No exílio chileno, fui conversar com a [Maria da] Conceição Tavares e, por indicação dela, comecei a fazer a Escolatina, a excelente escola de pós-graduação em Economia da Universidade do Chile. A formação era toda marxista: Economia Política 1 era o primeiro tomo d'O capital; Economia Política 2 era o segundo tomo; Economia Política 3 era o terceiro. E ainda tinha uma disciplina chamada "A transformação dos valores em preços" [risos].

Ainda com relação ao Chile, eu gostaria de fazer uma ressalva. Dentre os vários intelectuais brasileiros que lá estavam quando o Allende foi eleito, tanto o Fernando Henrique como o Almino Afonso não quiseram permanecer na experiência socialista! Diferente do [José]Serra, que foi preso e quase morreu. Apesar de ter se tornado um tucano horroroso, ele nunca negou essa experiência. Não é como o Aloysio Nunes, que virou um arrependido. O Serra sempre deu testemunho do que havia acontecido no Chile: foi horrível, foi uma ditadura. Isso tem que ser dito dele. E quando foi ministro da Saúde, ele quebrou a patente de medicamentos para a Aids - diferentemente do que o Brasil está fazendo agora, tentando impedir a quebra de patentes das vacinas contra a Covid-19, um absurdo!

Além da parte acadêmica, nos reuníamos em grandes encontros políticos. Algo que continuamos a fazer quando retornei a Paris, uma espécie de grandes fóruns. Foi também no Chile minha primeira tentativa de organização política no feminismo, pois já havia me tornado feminista em minha passagem pela França. Era um pequeno grupo, com quatro brasileiras. A gente escrevia, tinha o jornal dos exilados. Nunca na minha vida deixei de ser militante.

Revista Plural Como você vivenciou o embate entre os partidos comunistas oficiais e o surgimento da "nova esquerda", como o próprio movimento feminista? Qual era seu posicionamento em relação a isso? Naquele momento, quais os diálogos possíveis entre marxismo e feminismo?

Maria Lygia Quartim de Moraes Quando eu cheguei à França pela primeira vez, já havia sido formado um grupo de mulheres. Era o grupo da Danda Prado, que havia sido do PCB, mas se tornara muito crítica ao partido. O grupo era formado também por latino-americanas e se chamava "Nosotras". Era composto por mulheres mais velhas, muitas das quais casadas com diplomatas. Eu ia sempre à França e cheguei a participar de uma reunião com a Danda. Mas, naquele momento, o grosso dos exilados brasileiros estava em Cuba ou no Chile, país para o qual também fui. 
E quem estava no Chile? Zuleika Alambert, uma das poucas mulheres do comitê central do PCB, com seu esposo. Ela era a figura mais ortodoxa e careta que existia! Claro que ela teve um papel importante, porque acolheu muitas mulheres, viúvas e parentes de militantes, sem nenhuma formação política, que tinham recebido aquela situação como uma bomba em suas vidas. E o PCB tinha o espaço, o acolhimento, e foi importante o trabalho que a Zuleika fez. Mas ela organizava essas mulheres daquela forma mais ortodoxa do partidão! Eu me lembro que a Ana Matilde Mota, uma amiga querida e ex-dirigente da VAR [Vanguarda Armada Revolucionária Palmares], outras duas mulheres e eu começamos a ir às reuniões organizadas pela Zuleika. E no encontro debatiam uma questão de calendário, dia da paz, dia disso, dia daquilo, então eu levantei e falei: "Proponho que o dia 8 de outubro seja o dia do guerrilheiro heroico" [risos]. Foi mais pra marcar posição.

Anos depois, quando retorno à França, foi chegando tanto o pessoal do partidão - e o PC francês era poderosíssimo e também acolhedor -, como o pessoal da extrema esquerda. Na verdade, o grupo de mulheres brasileiras no exílio começa muito radical com as meninas do grupo chamado "Ponto de Partida”. Depois é que vai mudando e passa a receber brasileiras que foram para a França para estudar, como a querida Lucila Scavone, a Maria Betania Dávila, a Anette Goldberg.

Outros grupos haviam se formado antes. Quando cheguei, participei da organização de um grupo menor. Lembro-me de que Fúlvia Rosemberg e Albertina Costa faziam parte, além de mais umas dez outras mulheres. Estava também a Zuleika. E qual que era o tema da discórdia? As feministas queriam discutir a família, e as comunistas ortodoxas queriam privilegiar a questão do trabalho. Não que esse tema não fosse importante, mas, sem entrar na questão específica da opressão da mulher, na questão do patriarcado, ficaríamos de novo na tese de que o socialismo resolveria tudo. Depois, com a formação do "Círculo de Mulheres", em 1974, o núcleo feminista ganhou força e a ala da Zuleika foi perdendo espaço.

Zuleika e eu nos desentendíamos o tempo todo. Foi apenas na França que ela mudou de posição com respeito ao feminismo. Ela era uma dirigente importante do PCB e era casada com o Armênio Guedes, que, no exílio, se apaixonou pela Cecília [Maria Cecília Comênego], com quem ficou até o final da vida. Viver na França e se separar de Armênio permitiram uma mudança radical em sua vida. Vou te contar como foi meu reencontro com ela. Eu já havia retornado ao Brasil em 1975 e fiquei muito próxima da Ruth Escobar. Certo dia, após a Anistia de 1979, a Ruth me chamou para dizer que a Zuleika havia regressado e gostaria de fazer uma explanação sobre sua experiência como feminista - e me perguntou se eu poderia mediar a mesa. Na noite do evento, eu estava na frente do Teatro Ruth 
Escobar quando vejo uma motocicleta chegando, fazendo aquele barulho. Desce uma figura toda de preto, de couro: Zuleika Alembert! Eu quase caí dura [risos]. Ela tinha virado uma feminista radical e chegou raivosa! Você não imagina o que foi a lavação de roupa suja, pois a turma do partidão compareceu em peso. Teve até argumento do tipo "vocês homens não sabiam lavar as próprias cuecas e nos obrigavam a lavá-las”. Foi a maior gritaria, os caras berravam! Não deixou de ser cômico, por outro lado. Nunca me esquecerei daquela chegada heroica, de motocicleta e de couro! Foi uma das coisas mais maravilhosas que eu já vi na minha vida [risos].

Mas, voltando à França: eu continuei acompanhando o grupo feminista francês mesmo após meu retorno ao Brasil. Mantive contato seja por correspondência, porque nós tínhamos o jornal "Nós Mulheres" e enviávamos para elas, que o vendiam em Paris, seja porque eu ia para a França no mínimo duas vezes ao ano; então posso dizer por onde é que as coisas passavam. Elas tinham se subdividido em grupos: tinha o grupo de sexualidade, o grupo de psicanálise etc. O grupo acolheu muitas argentinas e uruguaias, e a maior parte das brasileiras voltou em 1979 com a lei da Anistia.

Em resumo, o que havia dividido feministas e comunistas? Primeiro, a questão da família, como já comentei. Depois, o feminismo rompeu de vez por defender a não "mixicidade", ou seja, por optar por reuniões apenas entre mulheres. E o motivo era muito óbvio: éramos caladas em reuniões mistas! Apenas três mulheres falavam: a Helena Hirata, minha cunhada Maryse Farhi e eu. Isto é, falávamos de vez em quando; às vezes, até tremíamos para falar. De resto, era uma "macharia", só os homens falavam.

Revista Plural Você volta ao Brasil em 1975 e se integra aos jornais de esquerda "Movimento" e "Em tempo". Como foi sua atuação na imprensa alternativa? E como foi sua inserção no Cebrap (Centro Brasileiro de Análise e Planejamento)? Com quem dialogava nesses espaços? De que modo essas experiências interferem em sua carreira?

Maria Lygia Quartim de Moraes Do exílio, nós víamos com grande entusiasmo o aparecimento da imprensa alternativa. Primeiro teve o "Opinião", financiado pelo Fernando Gasparian. Alguns jornalistas que trabalhavam nesse jornal resolveram fundar o "Movimento" para ter mais liberdade, como o Bernardo Kucinski e o Raimundo Pereira - este, um dos dirigentes do jornal. Outro fato importante naquela ocasião era o Cebrap e, sem dúvida, a grande novidade era o 
Chico de Oliveira. Aquele seu texto era algo extraordinário7! O Cebrap integrava diferentes intelectuais, mesmo que não fossem funcionários; eram poucos os que tinham vínculo de pesquisador assalariado. O Chico de Oliveira estava tanto no Cebrap como no "Movimento", assim como o Guido Mantega, que eu havia conhecido em Paris por intermédio do Eduardo Abramovay, com quem me relacionava. Quando cheguei ao Brasil, participei imediatamente do "Movimento", no grupo de economia, onde estavam Bernardo, Guido, Chico e eu.

Depois de um certo tempo, o Rui Falcão, ex-prisioneiro político que tinha ficado anos na cadeia, também passou a integrar nossa editoria de economia. No entanto, havia uma visível relação do Raimundo Pereira, que era uma grande figura, com o PCdoB. Isso foi cansando especialmente uma turma que era bem mais à esquerda; então, do "Movimento" vai sair o "Em tempo", para onde vou.

Já minha relação com o Cebrap é bastante específica: naquele momento, a instituição trabalhava com projetos através de contratos com grupos de pesquisa. Eu fiz parte de um desses grupos, que fez um estudo sobre economia brasileira coordenado pelo Chico de Oliveira. De todo modo, eu podia frequentar os encontros e seminários.

É nesse contexto que decidi fazer o doutorado no Brasil. Eu queria ser orientada pelo Juarez Brandão Lopes, mas, como ele já tinha um número absurdo de orientandos, o Fernando [Henrique Cardoso] sugeriu que eu fizesse com a Carmute [Maria do Carmo Campello de Souza], dizendo que, posteriormente, eu poderia passar para o Juarez. Assim, fui ser orientanda da Carmute, com um projeto sobre o setor estatal da economia, que eu estudava junto com o Guido.

Eu continuava militando no feminismo e conseguia publicar artigos sobre as mulheres no "Movimento", ninguém censurava. Até que, em 1978, a FCC [Fundação Carlos Chagas] fez o primeiro concurso de pesquisa sobre a mulher. Convidei a Cynthia Sarti, que havia sido secretária do Fernando no Cebrap e quem eu conhecera por intermédio do Guido, para escrever algo em parceria - e nós ganhamos o projeto. Certo dia, conversando com o Eduardo, ele pergunta: "Por que você vai fazer essa tese sobre economia que te deixa com cara de infeliz? Você gosta tanto do que você faz sobre a questão das mulheres. Por que não muda de tema de tese?". E ele tinha razão. Mas foi complicado, porque o Guido não ficou muito contente. Para ajudar, ele e a Cynthia já haviam rompido. Então era como se eu tivesse ficado do lado dela $-\mathrm{e}$, na verdade, foi isso. $\mathrm{O}$ feminismo foi mais importante, ganhou $\mathrm{o}$

7 Trata-se do ensaio "A economia brasileira: crítica à razão dualista”, publicado originalmente em 1972 no segundo número da revista Estudos Cebrap e reeditado nove anos depois (Oliveira, 1981). 
feminismo. Por fim, nem mudei de orientação; falei para a Carmute que ia escrever uma tese sobre mulheres, ela aceitou, ganhei bolsa da Fapesp. Na ocasião, também recebi um convite da Carmen Barroso para trabalhar na FCC, onde fiquei como bolsista por mais dois anos. Em 1980, contudo, decidi não aceitar o trabalho de pesquisadora da fundação, me dei um ano sabático e fui pra França.

Revista Plural Poderia comentar sobre sua experiência no grupo "Nós Mulheres", do qual você foi uma das fundadoras? Como foi seu encontro com os movimentos sociais que se fortaleciam no país naquele momento? Especialmente em relação aos movimentos de mulheres, como ocorriam essas aproximações? Até que momento você atua de forma organizada no movimento feminista? Por quê? Maria Lygia Quartim de Moraes Como voltei antes da Anistia, eu já estava no primeiro grupo que se dizia feminista no Brasil, o "Nós Mulheres" - uma evidente homenagem ao "Nosotras". Fazer as entrevistas, contatar as lideranças de mulheres, discutir os rumos do feminismo e produzir o jornal ajudou no processo de nosso crescimento pessoal, apesar das divergências ocasionais. Por exemplo, naquela época, mulher não saía sozinha. Então, íamos em grupo às baladas, só entre mulheres, e dançávamos entre nós, ou íamos a algum restaurante. Isso pode parecer ridículo hoje, mas, naquele momento, não era permitido. A nova geração não tem ideia das barreiras que as gerações anteriores tiveram que superar. É importante lembrar, memória é boa para isso também, para dizer "olha, foi uma luta conquistar tais coisas!”. E não é verdade dizer que, uma vez conquistado algum direito, já podemos descansar. Ao contrário, todas as conquistas estão sempre sujeitas a retrocessos, como estamos vivendo agora.

O "Nós Mulheres" tinha várias figuras, algumas ligadas à Igreja Católica, outras não. Distribuíamos e discutíamos o jornal em clubes de mães e associações de donas de casa. Com o pretexto de organizar encontros para o dia da mulher, o ano todo desenvolvíamos encontros e discussões. Era um "grupão", autointitulado "coordenação", do qual participavam jornalistas, feministas independentes, mulheres de entidades variadas; não havia muita exigência em dizer quais grupos ou quantas pessoas cada mulher estava representando. Era muito democrático, uma espécie de grande assembleia, essa política dos corpos presentes de que fala Judith Butler ${ }^{8}$.

8 Menção ao livro Corpos em aliança e a política das ruas, de Judith Butler (2018), publicado originalmente em 2015. 
Essa ligação com os movimentos populares era uma regra da esquerda de então. Acredito que a saída da militância desses espaços foi o começo da entrada de movimentos religiosos, porque na política não há espaço vazio. Outro dia, participei de uma roda de conversa e estava criticando os evangélicos, quando a querida Magali [Mendes] ${ }^{9}$ comentou: "Olha, Maria, lá nas minhas baixadas eu tenho que trabalhar com as evangélicas”. Ela estava certa, devemos distinguir. Há uma liderança horrorosa, escrota, machista, que faz todo seu discurso em cima da submissão da mulher ao homem e dos fiéis ao pastor. Não podemos confundir isso com a necessidade de proteção de grupos vulneráveis, os quais não podem contar com o Estado, sofrem a pressão das milícias e do tráfico nas periferias e encontram, na igreja, uma salvação. Acho que a responsabilidade total é nossa, desse Estado, que nunca se fez laico, e dos tucanos, com seus projetos de caráter antissocial.

É também interessante entender qual foi a reação da esquerda com o crescimento do movimento de mulheres, levando em conta que estávamos em plena ditadura. Estava óbvio que o movimento de mulheres não atraía o mesmo grau de repressão - claro, eu fui muito ameaçada, mas tinha muito mais relação com meu passado na militância armada, de quem eu era irmã ou viúva, do que com minha militância feminista. E diante do êxito dos encontros de mulheres, o MR-8 quis fazer um "entrismo". Esse grupo tinha uma posição muito estranha, estava ligado ao [Orestes] Quércia e nada tinha a ver com o primeiro MR-8 [Movimento Revolucionário 8 de outubro]. Aí começou uma briga entre organizações tradicionais em torno da disputa do movimento de mulheres, que nunca deixou de ser importante. Chegou a ter briga física por conta de decisões de algumas mulheres que eram favoráveis a seus partidos, uma vergonha. Qual foi a decisão do "Nós Mulheres"? Decidimos sair do grupão e não participar mais dessa grande assembleia.

Resolvemos, então, falar de nós, de nossas questões, fazendo algo que já tinha sido realizado por outras feministas, que era o chamado "grupo de reflexão", e passamos a nos reunir nas casas das integrantes. É esse grupo do "Nós Mulheres" que participa da organização do "Encontro Feminista de Valinhos" em 1980 - o que, rigorosamente, marca minha última participação nesses encontros. Por uma série de razões. Primeiro, porque eu passei meio ano na França e, na volta, participei da organização do Festival de Mulheres, com a grande Ruth Escobar. Depois, porque exatamente no dia 16 de novembro de 1982, isto é, um dia após as

9 Magali Mendes é historiadora, funcionária aposentada da Unicamp e militante do movimento negro. Coordena a formação de Promotoras Legais Populares na Associação Cida da Terra, em Campinas - SP. 
eleições que tinham finalmente mudado a história, e que tinham eleito o Franco Montoro $^{10}$, eu defendi minha tese de doutorado.

Por fim, vale dizer que houve uma burocratização do movimento feminista, virou tudo cabide de emprego. Sempre fui muito crítica desse feminismo profissional. Recusei a participar de conselhos porque logo percebi que aquilo ia depender de quem estaria nos cargos executivos - veja hoje, por exemplo, quando o ministério que deveria defender os direitos das mulheres está nas mãos de uma sociopata $^{11}$. E uma série de pessoas ficou viciada em viver desse modo, formando grupos que se eternizam nos aparelhos estatais, que se autorreproduzem.

Revista Plural Você defendeu seu doutorado na USP em 1982 e, a partir 1983, passou a atuar como professora universitária: primeiro na UFBA (Universidade Federal da Bahia), depois na Unesp (Universidade Estadual Paulista) e, finalmente, na Unicamp (Universidade Estadual de Campinas). Quais principais diferenças você sentia em relação a seus trabalhos anteriores? Como percebe esse trânsito para a academia?

Maria Lygia Quartim de Moraes Naquele momento, ao ter uma tese de doutorado defendida, você era cobiçada por todos. Fui à UFBA com uma bolsa de recém-doutor que era excelente. Eu era a única doutora nas Ciências Sociais e fui contratada para trabalhar na área de economia do CRH [Centro de Estudos e Pesquisas em Humanidades], um dos espaços mais prestigiosos da Bahia. Dei aula na pós-graduação e fui também uma das fundadoras do NEIM [Núcleo de Estudos Interdisciplinares sobre a Mulher], fazendo várias parcerias entre o núcleo e a FCC. Mas foi um período muito complicado, marcado por greves na universidade, pela falta que eu senti de São Paulo e pelo fim de meu relacionamento de então.

Como eu já tinha decidido seguir carreira na universidade, voltei da Bahia e fui conversar com minha grande amiga Carmen Junqueira, que era coordenadora da Pós-Graduação em Ciências Sociais na PUC. Para minha surpresa, o Octavio Ianni tinha uma mesa na sala da Carmen e estava lá no momento. Eu gostava muito dele, conversamos entre nós três e foi ele quem comentou sobre a vaga na Unesp de Araraquara. Acabei indo para lá e foi nessa ocasião em que realmente aprendi a

10 Nas “eleições gerais" de 1982, foi possível votar em representantes para câmaras legislativas municipais, assembleias legislativas estaduais, Câmara dos Deputados, um terço do Senado e prefeituras municipais (exceto as das capitais e aquelas consideradas “áreas de segurança”). Além disso, pela primeira vez desde 1965, houve eleição para representantes dos governos estaduais e o estado de São Paulo elegeu Franco Montoro como governador (1983-1987).

11 Alusão ao atual Ministério da Mulher, da Família e dos Direitos Humanos, cuja ministra é Damares Alves. 
ser professora. Isso porque, na Bahia, especialmente por conta das greves, acabei dando mais conferências. Ser professora era diferente.

Posso dizer que foi outro período difícil, porque era uma nova vida. Eu havia começado a fazer terapia ainda na Bahia, uma forma de trabalhar tudo que eu tinha vivido, inclusive o sofrimento. Até então, minha vida tinha sido cheia de desafios, de encontros e debates em grupos, de intensa militância. Quer dizer, tudo aquilo que tinha sido o charme, o atrativo dos últimos anos, foi alterado por esse novo momento. Aprendi a dar aula, a ter uma outra rotina, a criar uma disciplina. As classes chegavam a ter 100 estudantes. Tinha também a questão do cansaço: por conta da viagem, eu voltava de Araraquara exausta. Fiquei por lá oito anos e dei aulas de Teoria Social, de Marx, Escola de Frankfurt. Gostava dos estudantes, mas estava desconfortável em Araraquara, percebi que não estava feliz.

Então surgiu o concurso da Unicamp. A Ana Maria Goldani foi quem me ligou para dizer que iam abrir duas vagas e já explicou que o ambiente estava muito dividido. Uma loucura: como ninguém confiava em ninguém, todo o departamento de Sociologia fez parte da banca. Eram 16 membros! Dei uma boa aula sobre democracia e fiquei em segundo lugar.

No primeiro semestre, me passaram a disciplina Sociologia de Durkheim no noturno; no segundo, Sociologia de Marx, também no noturno. As duas para o primeiro ano, ou seja, a turma teve duas disciplinas seguidas comigo e pensei que isso deveria mudar. Somado a essa questão, percebi que boa parte dos docentes mais antigos só dava aula na pós-graduação. Então, quando eu fui chefe de departamento, fiz uma pacificação: somos todos doutores, somos todos iguais, todos devemos dar aula na graduação se quisermos dar aula na pós. E isso foi uma maravilha, todo mundo entrou nesse sistema e várias tensões foram resolvidas, o ambiente ficou bem mais cordial. Esse período também foi marcado pela falta de contratação de docentes - o que, por um lado, contribuiu para que o grupo que já estava lá se aproximasse; por outro, não foi nada bom porque formou um gap geracional. De todo modo, trabalhar na Unicamp foi um sonho, ter um espaço como o Pagu [Núcleo de Estudos de Gênero] também. Havia a tropa marxista no IFCH [Instituto de Filosofia e Ciências Humanas] formada por Ricardo Antunes, Márcio Naves, Marcelo Ridenti e eu. Tive relações de amizade com várias pessoas, como a Adriana Piscitelli, a Iara Beleli, o próprio Ricardo, as queridas Bibia Gregori [Maria Filomena Gregori] e Heloísa Pontes. Além da equipe maravilhosa que trabalhava lá: Magali Mendes, Elizabeth Oliveira, Suely Borges Costa, Maria Cimélia Garcia e Marilza Aparecida da Silva. Nossa relação era muito boa, gostava desse pessoal todo, criei laços afetivos. 
Nos primeiros anos de Unicamp, mudou o formato de bolsas e era necessário criar um grupo de pesquisa. Foi no mesmo período em que minha filha engravidou da minha neta Cleo. E aí resolvi estudar infância. Montamos um grupo com Cynthia Sarti, Eleonora Menicucci e Lucila Scavone.

Outro projeto de grande impacto coordenado por mim foi o "Documentos e memórias da repressão e da resistência política - Brasil, 1964-1982”, que formou muitos pesquisadores e pesquisadoras entre 2000 e 2007. Pudemos nos debruçar sobre o acervo do "Brasil: Nunca Mais" que, naquele momento, ainda não se encontrava digitalizado e seu único exemplar brasileiro estava sob responsabilidade do AEL [Arquivo Edgard Leuenroth]. O Mário Augusto Medeiros Silva teve uma participação fundamental como bolsista. O evento que antecipou o projeto foi muito marcante, ocorreu em março de 1996, quando organizei o seminário "A Revolução Possível" no IFCH.

Fiz ainda vários projetos vinculados ao CNPq [Conselho Nacional de Desenvolvimento Científico e Tecnológico] que debatiam direito de família, justiça transicional, teorias e militâncias feministas, entre outros temas. Orientei muitos trabalhos de mestrado e doutorado, em pesquisas que nem sempre abordavam gênero, feminismo ou marxismo, mas temas que me despertavam interesse, porque eu tenho essa abertura.

Por fim, vale dizer que tive a honra de presidir a Comissão da Verdade e Memória “Octavio Ianni” da Unicamp, cuja iniciativa partiu da reitoria ${ }^{12}$. Você conhece bem todo esse período porque tua contribuição foi fundamental, como foi publicamente reconhecido. Tivemos apoio da instituição, que acatou nossa solicitação de bolsas para integrar estudantes nas pesquisas da comissão. Enfim, sou muito grata à Unicamp, que virou minha segunda casa.

Revista Plural Você publicou um livro em dois tomos com artigos escritos nos últimos 40 anos: Marxismo, psicanálise e ofeminismo brasileiro (2017). Como foi e como é trabalhar com essa tríade marxismo/feminismo/psicanálise? Quais resistências enfrentou ou enfrenta? E como foi revisitar esses textos? Quais você considera os pontos fortes e as possíveis lacunas de sua produção?

Maria Lygia Quartim de Moraes Grande parte dos textos que compõe os dois tomos do livro faz parte de minha tese de doutorado de 1982 e da tese de livre docência de 1995. Sempre tive dificuldade em retornar a textos anteriores e, apesar de ter

12 A Comissão da Verdade e Memória “Octavio Ianni” da Universidade Estadual de Campinas foi criada pela portaria GR-111, de 20 de setembro de 2013, publicada no Diário Oficial de São Paulo em 24 de setembro de 2013. 
sido convidada a publicá-los, sempre achei que precisariam antes de uma revisão. O problema foi que o doutorado, por exemplo, fora escrito na base da máquina de escrever, o que implicaria enorme trabalho de reescrita. Deixei de lado, por exemplo, toda uma análise da situação da mulher no trabalho, pois os dados só iam até 1980. Em compensação, preservei a análise sobre o movimento feminista, porque faz parte da historiografia dos anos 1970-80, com a descrição dos acontecimentos em um estilo próximo ao jornalismo. Já a tese de livre docência foi aproveitada na íntegra. O livro também traz artigos que foram inovadores em seu tempo. É o caso de "A questão feminina", de 1974. Sem dizer que, em casos como esse, sempre aparece uma introdução que conta a trajetória do artigo ou texto.

A ideia inicial era fazer um só volume, mas, por sugestão da própria editoria da coleção Trajetórias, foram publicados dois volumes. Por conta do tamanho, deixei para uma outra publicação tudo o que escrevi sobre a questão da experiência do exílio, sobre o tema da memória e toda minha produção dos últimos 20 anos. Vamos ver se ainda reúno todo esse material! Mas o melhor da publicação dos dois tomos foi o fato de ter sido o primeiro ebook da Unicamp. E esse formato permitiu que eu incluísse fotos e material iconográfico. Em razão disso, tivemos inúmeros problemas técnicos, pois os programas mudavam e alteravam o texto. Mas, valeu a pena: aí estão os dois tomos de livre acesso para quem quiser lê-los. Sinceramente, gosto muito do resultado!

Você me pergunta se houve alguma resistência com respeito ao meu uso do marxismo e da psicanálise. A resposta é: nenhuma resistência ou rejeição. $\mathrm{Na}$ verdade, posso dizer que ocorreu o inverso. Minha tese de doutorado, por exemplo, não incluiu nenhum capítulo teórico inicial, como ainda continua sendo obrigatório em muitas faculdades. E a banca, que fora escolhida sem minha interferência ou sugestão, como sói acontecer, me deu a nota máxima. O mesmo ocorreu na livre-docência.

Revista Plural Temas como "identitarismo"e "interseccionalidade" estão presentes nas discussões atuais das Ciências Sociais e das militâncias políticas. Sobre o primeiro, embora o conceito de "políticas identitárias" tenha surgido no cerne da luta feminista socialista antirracista, tomou um rumo bastante diferente da proposta inicial, como assinala Asad Haider (2019). Em relação à "interseccionalidade", algumas teóricas da reprodução social apontam que o termo não daria conta da própria lógica da intersecção. Nos dois casos, parece estar em cena um problema que é tanto teórico como político. Qual sua opinião sobre isso?

Maria Lygia Quartim de Moraes Veja, em meados dos anos 1980, a FCC recebeu 
uma verba para fazer um balanço da "Década da Mulher"13, e a Carmen Barroso perguntou se eu poderia escrever sobre a participação das ONGs. Então perguntei: “ONG? O que é isso?”. Ela respondeu: “Ah, são os movimentos sociais. Os americanos chamam assim, de organizações não governamentais”. E todo mundo começa a usar ONG sem ter nenhuma ideia da origem e do quanto isso despolitiza a questão. Posteriormente, vieram dessas agências financiadoras termos como "masculinidades”, depois “emoções”... uma falta de rigor! Já entraram em moda vários outros debates, como o descolonial, o Sul Global, ou a interseccionalidade, o identitarismo.

Tenho lido bastante sobre aquilo que seria uma perspectiva unitária da relação entre gênero, raça e capitalismo. Pelo que entendo, é uma perspectiva mais dialética do que a chamada interseccionalidade, se bem que ambas têm a mesma preocupação, pois o efeito subjetivo das diferentes opressões não comporta raciocínios do tipo: aqui o que me pega é o capitalismo; aqui o gênero; aqui a raça. Ao mesmo tempo, o fato de que as mulheres sejam oprimidas em praticamente todas as sociedades conhecidas aponta para a relevância da opressão de gênero.

Foi a partir daquela maravilhosa intervenção do grupo chileno Las Tesis ${ }^{14}$ que comecei a ler os textos da antropóloga Rita Segato. E cada vez mais acho que sua proposta teórica é a mais consistente no sentido de conseguir dar conta do objeto de análise. Em Las estructuras elementales de La violencia, o patriarcado é explicado não apenas como a organização definidora do status dos diferentes membros do grupo familiar em todas as culturas que já existiram e das quais temos conhecimento, mas também como um corpo simbólico. Em outras palavras, o sistema patriarcal tem como suporte a assimetria entre os dois termos do gênero, em que um polo concentra o poder da violência e o status privilegiado, enquanto o outro é colocado numa situação subalterna. Nesse sentido, a construção da masculinidade se faz pelo "mandato", como Segato define, em que a fraternidade dos homens se constrói pelo compartilhamento do exercício da violência e da opressão sobre as mulheres. Concluindo: cumplicidade entre os homens é um elemento indispensável para que a estrutura patriarcal permaneça, e essa cumplicidade supõe a continuidade da opressão das mulheres. Essa relação assimétrica, segundo a autora, cria um protótipo que vai ser reproduzido no processo colonial e no racismo. Nos textos

13 A “Década da Mulher (1976-1985)" foi proclamada pela Organização das Nações Unidas (ONU) após a celebração da I Conferência Mundial sobre as Mulheres realizada no México em 1975.

14 O coletivo feminista Las Tesis ganhou repercussão internacional após participar dos protestos contra as políticas de austeridade do presidente chileno Sebastián Piñera em 2019. Com a performance "Um violador em tu camino" [Um estuprador em seu caminho], as integrantes denunciaram a violência patriarcal e as repressões dirigidas às mulheres. 
de Rita, a questão do descolonial ganha substância. Enfim, como você pode ver, estou aprendendo muito com ela.

Revista Plural Você tem defendido, em apresentações e entrevistas recentes, um "feminismo socialista". Poderia desenvolver melhor o que considera como "feminismo socialista"? Quais seriam as autoras/teóricas/ativistas? Quais as contribuições ao debate teórico e ao debate político? Qual seria diferença entre esse "feminismo socialista" o o "feminismo classista" ou "marxista"?

Maria Lygia Quartim de Moraes Eu uso isso sem muito rigor, na verdade. Muitas vezes, se você usar marxista, vem uma série de preconceitos. E, nesse momento, precisamos pensar em alianças. Na ditadura, por exemplo, não podíamos falar "marxista", então a gente usava "materialista". Então acho interessante, em alguns espaços, usar "socialista" para evitar preconceitos. Eu poderia falar simplesmente "feminismo anticapitalista", mas prefiro não definir pelo negativo.

E isso interfere em outra questão, que é pensar a classe revolucionária. Concordo com a crítica que Domenico Losurdo faz a uma concepção "obreirista" do processo revolucionário. Tanto a Revolução Chinesa, como a Cubana, sem se falar das guerras de libertação nacional, não se enquadram no modelo clássico da classe operária como vanguarda revolucionária. O potencial revolucionário do feminismo (em toda a vasta gama de femininos anticapitalistas) não precisa de justificativa: é uma realidade observável em várias partes do mundo.

Também vale a pena lembrar que o fato de nós, mulheres, sermos as "cuidadoras" não é algo apenas negativo. É claro que o peso da dupla ou tripla jornada deixa as mulheres exaustas. Isso nos faz exploradas, com certeza. Mas não nos imbeciliza, porque ter empatia e enxergar os demais nos dá sensibilidade e nos faz pessoas melhores. Ao mesmo tempo, como observou com acuidade minha colega da Unifesp [Universidade Federal de São Paulo], Claudia Mazzei [Nogueira], é preciso não cair no risco da naturalização dos gêneros, insistindo na divisão entre trabalho de homem e de mulher. Trata-se, ao contrário, de dessexualizar a divisão do trabalho e educar os homens também para o cuidar. Razão pela qual acho a proposta de salário dona de casa, tal como defende Silvia Federici, um grande retrocesso.

Concluindo, as mulheres foram as mais radicais opositoras à candidatura de Bolsonaro, foram elas que saíram às ruas no "Ele não"

15 Ficaram conhecidas como "Ele Não" ou “\#EleNão" as manifestações populares lideradas por mulheres em setembro de 2018 que ocorreram em diferentes cidades do Brasil e do exterior para protestar contra a candidatura do então deputado Jair Bolsonaro à presidência da República. 
que estão sofrendo maiores perdas de direitos, ao mesmo tempo em que a violência e o feminicídio aumentaram nesses longos meses de pandemia. Não tenho apenas uma relação teórica, abstrata, com questão da opressão das mulheres. Minha relação é de corpo presente, de sentir na prática os retrocessos em nossos direitos e o antifeminismo oficializado por esse governo genocida. Então, eu acredito na potência revolucionária do feminismo.

\section{REFERÊNCIAS BIBLIOGRÁFICAS}

BUTLER, Judith (2018). Corpos em aliança e a política das ruas: notas para uma teoria performativa de assembleia. Rio de Janeiro: Civilização Brasileira.

FERNANDES, Florestan (2005 [1975]). A Revolução Burguesa no Brasil: ensaio de interpretação sociológica. $5^{\mathrm{a}}$ ed. São Paulo: Globo.

HAIDER, Asad (2019). Armadilhas da identidade: raça e classe nos dias de hoje. São Paulo: Veneta.

MORAES, Maria Lygia Quartim de (2017). Marxismo, psicanálise e ofeminismo brasileiro. Campinas: Unicamp/IFCH, Coleção Trajetórias n.9, 2v.

OLIVEIRA, Francisco (1981 [1972]). A economia brasileira: crítica à razão dualista. Petrópolis: Vozes/Cebrap.

SCHWARZ, Roberto et al (2017). Nós que amávamos tanto O Capital: leituras de Marx no Brasil. São Paulo: Boitempo Editorial.

WOOLF, Virginia (2004). Um teto todo seu. $2^{\mathrm{a}}$ ed. Rio de Janeiro: Nova Fronteira.

Recebido: 05/05/2021 | Aprovado: 04/06/2021 